\title{
Assessing prevalence of antibiotic resistant microbes on fresh marketed vegetables of Aizawl city
}

\author{
Karuppasamy Chellapandi , Lalsanglura Ralte, Lydia Malsawmtluangi, Luke Masih, Kiran Kumar Singh T. and \\ Dipankar Boro ${ }^{6}$
}

Department of Medical Laboratory Technology (MLT), Regional Instiute of Paramedical and Nursing Sciences (RIPANS), (G.O.I), Zemabwak, Aizawl. Mizoram. Pin- 796017. India.

Email: karuppskl27@gmail.com

Received 12 June 2014; Received in revised from 27 October 2014; Accepted 17 November 2014.

\begin{abstract}
Aims: The study was carried out to evaluate the isolation and identification of the prevalent bacterial flora and their antibiotic resistance pattern from fresh vegetables sold in the local markets of Aizawl town.

Methodology and results: Three vegetables:- Tomato (Lycopersicon esculentum), potato (Solanum tuberosum) and cabbage (Brassica Oleracea) were randomly collected from different vendors of three local markets in Aizawl town. All the vegetables were washed with double distilled water and cultured onto Mac-Conkey agar and sub-cultured into nutrient agar to obtain pure culture for the identification. Samples were analyzed to study the density of microorganisms by standard plate count (SPC). Mean microbial load ranged from $2.46 \times 10^{5}-11.85 \times 10^{5} \mathrm{CFU} / \mathrm{mL}$ for market $A ; 1.3 \times 10^{4}-$ $2.51 \times 10^{6} \mathrm{CFU} / \mathrm{mL}$ for market $\mathrm{B}$ and $1.09 \times 10^{5}-3.14 \times 10^{6} \mathrm{CFU} / \mathrm{mL}$ for market $\mathrm{C}$. Approximately 41 bacterial isolates made up of 7 genera of bacteria were made from the 3 vegetable groups. Enterobacter spp. (39.02\%), Klebsiella spp. (26.82), Proteus spp. (9.76\%), Staphylococcus spp. (9.76\%) and E. coli (4.88\%), Citrobacter sp. (4.88\%) and Serratia spp. $(4.88 \%)$ were the bacteria species isolated. Antibiotic sensitivity patterns of the isolates were determined and almost all of them were resistant to commonly used antibiotics. The percentage of Multi Drug Resistant (MDR) bacteria against the total load was very high $(80.5 \%)$, and the ESBL production is $62.16 \%$.

Conclusion, significance and impact study: Vegetable contamination with bacteria was observed in all the three markets $A, B$ and $C$. Raw vegetables from the markets were considered unfit for making fresh produce for human consumption and adequate cooking with proper handling before consumption is suggested.
\end{abstract}

Keywords: Aizawl, Antibiotic resistance, vegetable pathogens, vegetables quality.

\section{INTRODUCTION}

Fresh vegetables are essential parts of the diet of humans. Fruits and vegetables are rich in nutrients, micronutrients and vitamins which help the consumers from vitamin deficiencies, malnutrition and to get rid of the diseases related to these. Fruits and vegetables contain good amount of vitamins mainly vitamin $C$ and $A$, which are required for the treatment of most of the infections as a supplement along with the medicines (Kalia and Gupta, 2006).

Fruits and vegetables are exposed to microbial contaminations that are mainly due to the high nutrition, neutral $\mathrm{pH}$, micro nutrition and other favorable conditions required for the microbial growth. Vegetables harbor both human and plant microbes since they are widely exposed to the sewage contaminated soil, water and manures (Nguyen-the and Carlin, 1994; Carmo et al., 2004). These vegetables can also get contaminated with pathogenic microbes during harvesting, transportation, storage, transport containers, retailer handling etc. Due to these wide range of exposure to different source microbial flora of the vegetables greatly vary (Ray and Bhunia, 2007; Ofor et al., 2009).

Most microorganisms that are initially observed on whole fruit or vegetable surfaces are soil inhabitants which have members of a very large and diverse community of microbes. Transmission of microbes to these vegetables may also occur through vectors like soil particles, airborne spores and irrigation water. Microbes that harbor on the vegetable surface may cause spoilage due to favorable conditions found for their growth. Although spoilage microbes including bacteria, yeasts and moulds dominate, human pathogens like pathogenic bacteria, viruses and parasites occasionally present on vegetables are also documented (Hasan et al., 2006).

An increased number of microbial infections associated with consumption of fresh vegetables have been reported in recent years. Documented illnesses have been caused by bacteria, parasites, and viruses and are 
transmitted via many types of fruits and vegetables (Beuchat, 1996; Nyenje et al., 2012). Excessive and misuse of antimicrobials to control pathogens in animals and crops led to antibiotic resistance and transfer to human through contaminated food. Some researches show that antibiotic resistant bacteria also may be ingested with vegetables (Kilonzo et al., 2009). Vegetables such as corn, green onion and cabbage absorb antibiotics when grown in soil fertilized with livestock antibiotics contaminated manure (Kumar et al., 2005).

Antibiotic resistance is a major problem in agriculture, livestock and medical field for many reasons (CDC, 2005). First, antibiotic resistance found against the penicillin group of drugs, now it is increasing to antibiotics of fluoroquinolones and third generation cephalosporins. These are commonly used antibiotics to treat serious infections of bacteria in humans like Salmonella and Shigella species etc.

Consumption of vegetables and fruits mainly uncooked or unprocessed represents the direct human exposure to spoilage microbes found on them. In our current study, we assessed the prevalence of antibiotic resistant pathogens on fresh vegetables like potatoes, tomatoes and cabbage collected from markets.

\section{MATERIALS AND METHODS}

\section{Collection of sample}

During the study period i.e. from September, 2013 to February, 2014 a total of 27 samples (visits) of tomato, cabbage and potato were collected in sterile polythene bags from 3 different major vegetable markets (Zemabawk, Thuampui and Bara bazaar) of Aizawl town, Mizoram, North East India. All the samples were collected after at least one week gap, so that there is no repeated sampling from the same stock. All the samples in this study were freshly collected and hygienically packed transported to the microbiology laboratory, Department of Medical Laboratory Technology (MLT) of Regional Institute of Paramedical and Nursing sciences (RIPANS), Aizawl. The samples were processed immediately after collection; it was refrigerated at $2{ }^{\circ} \mathrm{C}$ to $8^{\circ} \mathrm{C}$ if processing was delayed more than one day.

\section{Isolation, enumeration and identification of bacteria by Standard Plate Count (SPC) method}

All the vegetable samples were rinsed thoroughly in a 250 $\mathrm{mL}$ beaker containing $100 \mathrm{~mL}$ of sterile distilled water. Then rinsed water samples or surface cleaned samples were serially diluted up to $10^{-7}$. A $0.1 \mathrm{~mL}$ of each dilution was spread on Mac-Conkey agar (HiMedia Pvt. Ltd. Mumbai, India) and the plates were incubated at $37^{\circ} \mathrm{C}$ for $24 \mathrm{~h}$ for isolation of bacteria (Khan et al., 1992). Total viable counts were determined by counting both red and non-red colonies on the Mac-Conkey plates. Based on the morphological characteristics, red and non-red colonies were selected from Mac-Conkey agar plate and sub cultured to Nutrient agar for identification by all the standard bacteriological methods viz. Gram staining, biochemical tests namely: IMViC (Indole, Methyl Red, Voges-Proskauer, citrate), triple sugar iron; and subculture on differential media (Eosin Methylene Blue (EMB) agar at $37^{\circ} \mathrm{C}$ and $44{ }^{\circ} \mathrm{C}$ for 24 to $48 \mathrm{~h}$; Mannitol salt agar and in Cystein Lactose Electrolyte Deficient (CLED) agar at $37^{\circ} \mathrm{C}$ ) and also in nutrient agar (Holt et al., 1994).

\section{Gram staining}

A loop full of overnight culture was placed on the slide with a drop of distilled water. Smear was prepared by spreading the drop of inoculum with inoculation loop. The heat fixed smear was first stained with crystal violet for 60 $\mathrm{sec}$. After rinse the slide, it was flooded with Grams iodine solution and was kept for $60 \mathrm{sec}$. Slide was again washed under the tap water and added $95 \%$ alcohol for $30 \mathrm{sec}$. After wash the slide, it was stained with saffranin for $60 \mathrm{~s}$. It was again rinsed under tap water and dried on paper towels. The cells were examined under the light microscope.

\section{Biochemical tests}

Biochemical tests were done according to Collee's Mackie \& McCartney Practical Medical Microbiology (Collee et al., 2011). Biochemical tests conducted in this study were as follows: Catalase Test, Triple Sugar Iron Agar (TSI) test, Hydrogen sulfide production $\left(\mathrm{H}_{2} \mathrm{~S}\right)$, Methyl Red (MR) test, Voges-Proskauer (VP) test, Citrate Utilization test, Nitrate reduction test, Indole production and Motility tests were performed to identify the bacteria up to the Genus level.

\section{Motility determination}

A small amount of Vaseline was placed at each corner of clean cover glass. Two loopful of the $24 \mathrm{~h}$ old culture of the organism from nutrient broth was placed at the center of the cover glass. A concavity slide was pressed over the cover glass, such that the depressions cover the culture drop and quickly inverted. The completed preparation was observed microscopically.

\section{Antibiotic susceptibility tests}

Briefly, the susceptibility of all the isolates against the antimicrobials was determined by Kirby-Bauer disc diffusion method in Mueller-Hinton agar (Bauer et al., 1966). The inoculum was prepared at a density adjusted to a 0.5 McFarland turbidity standard solution. Commercially available antimicrobial discs (HiMedia Ltd, Mumbai, India) of Aztreonam (AT10 = $10 \mu \mathrm{g}$ ), Nitrofurantoin $($ NIT200 $=200 \mu \mathrm{g})$, Ciprofloxacin $($ CF10 $=$ $10 \mu \mathrm{g})$, Ampicillin $(\mathrm{A} 10=10 \mu \mathrm{g})$, Ceftazidime (CFM5 = 5 $\mu \mathrm{g})$, Meropenem (MRP10 $=10 \mu \mathrm{g})$, Imepenem (IPM10 = $10 \mu \mathrm{g})$, Linezolid $(\mathrm{LZ30}=30 \mu \mathrm{g})$, Cefoxitin $(\mathrm{CX} 30=30$ $\mu \mathrm{g})$, Co-timoxazole $(\mathrm{CO} 30=$ Trimethoprim $2.50 \mu \mathrm{g}$ and Sulphamethoxazole $27.5 \mu \mathrm{g}$ ), Norfloxacin (NX10 = $10 \mu \mathrm{g}$ ), 
Table 1: Showing the microbial load on chosen vegetables from Aizawl Markets.

\begin{tabular}{llcc}
\hline $\begin{array}{l}\text { Sl. } \\
\text { No. }\end{array}$ & Name of isolates & $\begin{array}{c}\text { Number of } \\
\text { occurrence }\end{array}$ & $\begin{array}{l}\text { Percentage } \\
(\%)\end{array}$ \\
\hline 1. & Escherichia coli & 2 & 4.88 \\
2. & Enterobacter sp. & 16 & 39.02 \\
3. & Klebsiella sp. & 11 & 26.82 \\
4. & Proteus sp. & 4 & 09.76 \\
5. & Citrobacter sp. & 2 & 04.88 \\
6. & Staphylococcus & 4 & 09.76 \\
& sp. & & 04.88 \\
7. & Serratia sp. & 2 & $100 \%$ \\
\hline Total & & 41 & \\
\hline
\end{tabular}

Cephotaxime $($ CE30 $=30 \mu \mathrm{g})$, Amikacin $($ AK10 $=10 \mu \mathrm{g})$ and Clindamycin (CD10 $=10 \mu \mathrm{g})$ were placed on the inoculated agar plates and incubated in an upright position overnight at $37^{\circ} \mathrm{C}$. Sensitivity was recorded after $24 \mathrm{~h}$ of incubation by measuring the zone of inhibition formed around the antimicrobial discs. The results were expressed as Sensitive, Intermediate and Resistant by considering CLSI, 2012 guidelines.

\section{RESULTS}

Bacteria can cause fruits and vegetables to get mushy, slimy and make them produce bad odour. There are different spoilage bacteria which grow well at room temperature. The large number of microorganism's and their waste products causes the objectionable changes in odour, taste and texture. Antibiotic resistance is a worldwide problem in the medical society that continues to grow. It is again a major concern in public health that risk of consuming vegetables and fruits harboring drug resistant bacteria. Hence it is necessary to screen the vegetable, fruits and food items which we consume for the energy every day, since there is an enormous chance of getting food pathogens than from the other sources. For the current study, we have collected samples from three different local markets of Aizawl city, Mizoram, North eastern state in India.

\section{Total Viable Count (TVC)}

The microbial load of the samples varied with type and vendors or markets (Table 1). Range of microbial count was varied to different markets, it ranged from $2.46 \times 10^{5}$ to $11.85 \times 10^{5} \mathrm{CFU} / \mathrm{mL}$ for Zemabawk market $(\mathrm{A}), 1.3 \times 10^{4}$ to $5.92 \times 10^{5} \mathrm{CFU} / \mathrm{mL}$ for Thuampui market (B) and $1.09 \times 10^{5}$ to $3.14 \times 10^{6} \mathrm{CFU} / \mathrm{mL}$ for Bara bazaar market $(\mathrm{C})$. Tomato from the market $B$ had the lowest microbial load $\left(1.09 \times 10^{4}\right.$ $\mathrm{CFU} / \mathrm{mL}$ ) of all the samples collected while cabbage from market $C$ had the highest microbial load $\left(3.14 \times 10^{6}\right.$ $\mathrm{CFU} / \mathrm{mL}$ ). Among all the tomato samples least microbial load was found from market $B\left(1.3 \times 10^{4} \mathrm{CFU} / \mathrm{mL}\right)$ and highest from market $A\left(11.85 \times 10^{5} \mathrm{CFU} / \mathrm{mL}\right)$, potato from market $A$ had the least microbial count $\left(2.46 \times 10^{5}\right.$ $\mathrm{CFU} / \mathrm{mL})$ and highest from the market $\mathrm{C}\left(1.59 \times 10^{6}\right.$ $\mathrm{CFU} / \mathrm{mL}$ ). Cabbage had the least microbial count from market $\mathrm{A}\left(3.57 \times 10^{5} \mathrm{CFU} / \mathrm{mL}\right)$ and highest from the market C $\left(3.14 \times 10^{6} \mathrm{CFU} / \mathrm{mL}\right)$. Mean TVC (log CFU $\left./ \mathrm{mL}\right)$ and Standard deviation, Standard error of mean etc. were calculated statistically to find the significant difference in the microbial load of LF and NLF from the collected vegetables. There were significant differences found between LF and the NLF isolates. ( $p \leq 0.05)$ (Table 2).

\section{Percentage of isolates occurrence}

Bacterial isolates were isolated and identified upto the Genus level by sub culturing to MacConkey agar, Cystein Lactose Electrolyte Deficient (CLED) agar and Mannitol Salt Agar (MSA) and incubated at $37^{\circ} \mathrm{C}$ for $24 \mathrm{~h}$. By standard bacteriological tests viz. Gram staining, catalase test, coagulase test, IMViC, Triple Sugar Iron Agar (TSI) tests, Motility test and Eosin Methylene Blue (EMB) agar were used to identify to the genus level.

Table 2: Showing the percentage of the isolates from all the vegetable samples.

\begin{tabular}{|c|c|c|c|c|c|c|}
\hline \multirow{3}{*}{ Sampling sites } & \multicolumn{6}{|c|}{ Microbial load (CFU/mL) } \\
\hline & \multicolumn{2}{|l|}{ Tomato } & \multicolumn{2}{|l|}{ Potato } & \multicolumn{2}{|l|}{ Cabbage } \\
\hline & LF & NLF & LF & NLF & LF & NLF \\
\hline Zemabawk (A) & $11.85 \times 10^{5}$ & $7.12 \times 10^{5}$ & $3.67 \times 10^{5}$ & $2.46 \times 10^{5}$ & $8.22 \times 10^{5}$ & $3.57 \times 10^{5}$ \\
\hline Thuampui (B) & $5.92 \times 10^{5}$ & $1.3 \times 10^{4}$ & $3.46 \times 10^{5}$ & $3.45 \times 10^{5}$ & $2.51 \times 10^{6}$ & $1.22 \times 10^{6}$ \\
\hline Bara Bazaar (C) & $1.39 \times 10^{6}$ & $1.09 \times 10^{5}$ & $1.59 \times 10^{6}$ & $1.30 \times 10^{6}$ & $3.14 \times 10^{6}$ & $1.94 \times 10^{6}$ \\
\hline SD values & $4.1 \times 10^{5}$ & $3.7 \times 10^{5}$ & $7.1 \times 10^{5}$ & $5.8 \times 10^{5}$ & $1.2 \times 10^{5}$ & $7.9 \times 10^{5}$ \\
\hline$p$ values & 0.0459 & & 0.1201 & & 0.0319 & \\
\hline
\end{tabular}


Mal. J. Microbiol. Vol 11(1) 2015, pp. 40-46

Table 3: Showing the isolates Multi Drug Resistance patterns against the selected antibiotics.

\begin{tabular}{|c|c|c|c|c|c|c|c|c|c|c|c|c|c|c|c|c|c|}
\hline $\begin{array}{l}\text { SI. } \\
\text { no. }\end{array}$ & $\begin{array}{l}\text { Organism } \\
\text { (No. of isolates) }\end{array}$ & $\begin{array}{l}8 \\
\& \\
\end{array}$ & $\begin{array}{l}\stackrel{8}{\circ} \\
\stackrel{5}{\Sigma}\end{array}$ & 品 & $\stackrel{\circ}{<}$ & $\sum_{\substack{0 \\
0}}^{n}$ & $\begin{array}{l}8 \\
N \\
0 \\
0\end{array}$ & $\begin{array}{l}\stackrel{0}{2} \\
\frac{\hat{\alpha}}{\Sigma}\end{array}$ & $\stackrel{\circ}{\sum_{0}}$ & $\begin{array}{l}8 \\
y\end{array}$ & $\stackrel{8}{x}$ & 蛋 & $\stackrel{\circ}{x}$ & $\begin{array}{l}\circ \\
\text { 岂 }\end{array}$ & 妾 & 응 & $\begin{array}{l}\frac{0}{0} \\
\frac{\pi}{0} \\
\frac{1}{2}\end{array}$ \\
\hline 1. & $\begin{array}{l}\text { Escherichia coli } \\
(\mathrm{n}=2)\end{array}$ & $\begin{array}{l}1 \\
(50)\end{array}$ & 0 & $\begin{array}{l}1 \\
(50)\end{array}$ & $\begin{array}{l}2 \\
(100)\end{array}$ & $\begin{array}{l}1 \\
(50)\end{array}$ & $\begin{array}{l}1 \\
(50)\end{array}$ & 0 & 0 & 0 & $\begin{array}{l}1 \\
(50)\end{array}$ & $\begin{array}{l}2 \\
(100)\end{array}$ & $\begin{array}{l}1 \\
(50)\end{array}$ & $\begin{array}{l}1 \\
(50)\end{array}$ & 0 & $\begin{array}{l}1 \\
(50)\end{array}$ & $\begin{array}{l}1 \\
(50)\end{array}$ \\
\hline 2. & $\begin{array}{l}\text { Enterobacter } \\
\text { sp. } \\
(\mathrm{n}=16)\end{array}$ & $\begin{array}{l}6 \\
(37.5)\end{array}$ & $\begin{array}{l}12 \\
(75)\end{array}$ & $\begin{array}{l}6 \\
(37.5)\end{array}$ & $\begin{array}{l}10 \\
(62.5)\end{array}$ & $\begin{array}{l}9 \\
(56.25)\end{array}$ & $\begin{array}{l}9 \\
(56.25)\end{array}$ & $\begin{array}{l}4 \\
(25)\end{array}$ & $\begin{array}{l}6 \\
(37.5)\end{array}$ & $\begin{array}{l}9 \\
(56.25)\end{array}$ & $\begin{array}{l}10 \\
(62.5)\end{array}$ & $\begin{array}{l}6 \\
(37.5)\end{array}$ & $\begin{array}{l}4 \\
(25)\end{array}$ & $\begin{array}{l}9 \\
(56.25)\end{array}$ & $\begin{array}{l}5 \\
(31.5)\end{array}$ & $\begin{array}{l}7 \\
(43.75)\end{array}$ & $\begin{array}{l}12 \\
(75)\end{array}$ \\
\hline 3. & $\begin{array}{l}\text { Klebsiella sp. } \\
(\mathrm{n}=11)\end{array}$ & $\begin{array}{l}9 \\
(81.81)\end{array}$ & $\begin{array}{l}10 \\
(90.90)\end{array}$ & $\begin{array}{l}2 \\
(18.18)\end{array}$ & $\begin{array}{l}10 \\
(90.90)\end{array}$ & $\begin{array}{l}10 \\
(90.90)\end{array}$ & $\begin{array}{l}5 \\
(45.45)\end{array}$ & $\begin{array}{l}1 \\
(9.09)\end{array}$ & $\begin{array}{l}1 \\
(9.09)\end{array}$ & $\begin{array}{l}9 \\
(81.81)\end{array}$ & $\begin{array}{l}7 \\
(63.63)\end{array}$ & $\begin{array}{l}9 \\
(81.81)\end{array}$ & $\begin{array}{l}1 \\
(9.09)\end{array}$ & $\begin{array}{l}9 \\
(81.81)\end{array}$ & $\begin{array}{l}4 \\
(36.36)\end{array}$ & $\begin{array}{l}10 \\
(90.90)\end{array}$ & $\begin{array}{l}10 \\
(90.90)\end{array}$ \\
\hline 4. & $\begin{array}{l}\text { Proteus sp. } \\
(\mathrm{n}=4)\end{array}$ & $\begin{array}{l}2 \\
(50)\end{array}$ & $\begin{array}{l}3 \\
(75)\end{array}$ & $\begin{array}{l}2 \\
(50)\end{array}$ & $\begin{array}{l}3 \\
(75)\end{array}$ & $\begin{array}{l}2 \\
(50)\end{array}$ & $\begin{array}{l}2 \\
(50)\end{array}$ & 0 & 0 & $\begin{array}{l}2 \\
(50)\end{array}$ & $\begin{array}{l}1 \\
(25)\end{array}$ & $\begin{array}{l}3 \\
(75)\end{array}$ & $\begin{array}{l}1 \\
(25)\end{array}$ & $\begin{array}{l}2 \\
(50)\end{array}$ & $\begin{array}{l}1 \\
(25)\end{array}$ & $\begin{array}{l}3 \\
(75)\end{array}$ & $\begin{array}{l}3 \\
(75)\end{array}$ \\
\hline 5. & $\begin{array}{l}\text { Citrobacter sp. } \\
(\mathrm{n}=2)\end{array}$ & 0 & 0 & 0 & $\begin{array}{l}2 \\
(100)\end{array}$ & $\begin{array}{l}1 \\
(50)\end{array}$ & 0 & 0 & 0 & $\begin{array}{l}1 \\
(50)\end{array}$ & 0 & $\begin{array}{l}2 \\
(100)\end{array}$ & 0 & $\begin{array}{l}2 \\
(100)\end{array}$ & 0 & $\begin{array}{l}1 \\
(50)\end{array}$ & $\begin{array}{l}1 \\
(50)\end{array}$ \\
\hline 6. & $\begin{array}{l}\text { Staphylococcus } \\
\text { sp. } \\
(\mathrm{n}=4)\end{array}$ & $\begin{array}{l}3 \\
(75)\end{array}$ & $\begin{array}{l}2 \\
(50)\end{array}$ & $\begin{array}{l}2 \\
(50)\end{array}$ & $\begin{array}{l}4 \\
(100)\end{array}$ & $\begin{array}{l}2 \\
(50)\end{array}$ & $\begin{array}{l}2 \\
(50)\end{array}$ & 0 & 0 & $\begin{array}{l}2 \\
(50)\end{array}$ & $\begin{array}{l}2 \\
(50)\end{array}$ & $\begin{array}{l}2 \\
(50)\end{array}$ & $\begin{array}{l}3 \\
(75)\end{array}$ & $\begin{array}{l}2 \\
(50)\end{array}$ & $\begin{array}{l}1 \\
(25)\end{array}$ & $\begin{array}{l}1 \\
(25)\end{array}$ & $\begin{array}{l}3 \\
(75)\end{array}$ \\
\hline 7. & $\begin{array}{l}\text { Serratia sp. } \\
(n=2)\end{array}$ & 0 & 0 & $\begin{array}{l}1 \\
(50)\end{array}$ & $\begin{array}{l}1 \\
(50)\end{array}$ & 0 & 0 & 0 & 0 & $\begin{array}{l}1 \\
(50)\end{array}$ & $\begin{array}{l}1 \\
(50)\end{array}$ & $\begin{array}{l}1 \\
(50)\end{array}$ & 0 & 0 & 0 & 0 & 0 \\
\hline $\begin{array}{l}\text { Total } \\
\text { (\% res }\end{array}$ & $\begin{array}{l}(n=41) \\
\text { istance })\end{array}$ & $\begin{array}{l}21 \\
(51.21)\end{array}$ & $\begin{array}{l}27 \\
(65.85)\end{array}$ & $\begin{array}{l}14 \\
(34.14)\end{array}$ & $\begin{array}{l}32 \\
(78.04)\end{array}$ & $\begin{array}{l}25 \\
(60.97)\end{array}$ & $\begin{array}{l}19 \\
(46.34)\end{array}$ & $\begin{array}{l}5 \\
(12.19)\end{array}$ & $\begin{array}{l}7 \\
(17.07)\end{array}$ & $\begin{array}{l}24 \\
(58.53)\end{array}$ & $\begin{array}{l}22 \\
(53.65)\end{array}$ & $\begin{array}{l}25 \\
(60.97)\end{array}$ & $\begin{array}{l}10 \\
(24.39)\end{array}$ & $\begin{array}{l}25 \\
(60.97)\end{array}$ & $\begin{array}{l}11 \\
(26.82)\end{array}$ & $\begin{array}{l}23 \\
(56.09)\end{array}$ & $\begin{array}{l}30 \\
(73.17)\end{array}$ \\
\hline
\end{tabular}


A total of 41 isolates was isolated from all the types of vegetables collected. Isolated bacterial isolates were almost all Gram negative with only $5 \%$ of contribution made by Gram positive cocci i.e. Staphylococcus spp. of the total isolates. Physiological and biochemical tests showed that the isolated organisms comprised of seven genera viz. Enterobacter spp. (39.02\%), Klebsiella spp. (26.82\%), Escherichia coli (4.88\%), Citrobacter spp. (4.88 $\%)$ and Serratia spp. (4.88 \%) as Lactose Fomenters (LF) and Proteus spp. (9.76\%) as Non-Lactose Fermenter (NLF) and Staphylococcus spp. (9.76\%)of Gram positive cocci (Table 2).

\section{Antimicrobial resistance}

An antibiogram study of 41 isolates showed that the percentage of resistance was very high. Among the 41 isolates tested for drug resistance the higher percentage of resistance was found against Ampicillin (78.04\%), followed by $65.85 \%$ resistance to Nitrofurantoin and $60.97 \%$ against three antibiotics that Ceftazidime, Cephotaxime and Co-Timoxazole (Table 3). The antibiotics to which maximum isolates found sensitive were against Meropenem, Imepenem, Norfloxacin and Amikacin and only $12.19 \%, 17.07 \%, 24.39 \%$ and $26.82 \%$ isolates were found resistant to these antibiotics respectively. These experimental results also suggested that multi drug resistance of environmental bacteria is increasing and almost all the isolates were resistant to more than five antibiotics.

In this antibiogram study 15 antibiotics were used and any bacteria shows resistance to more than 7 antibiotics was considered to be Multi Drug Resistant (MDR) isolates. Only two isolated genus were showing resistance to all the antibiotics used i.e. Enterobacter spp. and Klebsiella spp. and the rest of the species contribute some percentage to Non-MDR isolates. The MDR analysis has shown that $85.37 \%$ of the isolates are MDR and only $14.63 \%$ are Non-MDR isolates

\section{Extended spectrum of $\beta$-lactamases}

All the Gram negative isolates have been tested for the Extended spectrum $\beta$-lactamase enzymes (ESBL) by standard bacteriological double diffusion synergy test (DDST) methods (CLSI, 2012). Of all the members of Enterobacteriaceae Gram Negative Bacilli (GNB) isolates Klebsiella spp. was found to be the highest ESBL producer that $29.73 \%$, followed by Enterobacter spp. (24.32\%). Proteus spp. (5.40\%) and E. coli $(2.70 \%)$ contributes very less percentage of ESBL productions, but $0 \%$ of isolates found positive for ESBL from the genus Citrobacter spp. and Serratia spp. (Table 4).

\section{DISCUSSION}

Freshly consumed vegetables especially those use in salad mixtures, have been implicated in food poisoning and thus hazardous to the health of the consumers. This could be linked to the fact that most of these vegetables are consumed without being subjected to the thermal process or even thorough washing (Lund, 1992). The microbial load present in fruits and vegetables are the direct reflection of the sanitary quality of the cultivation water, harvesting, transportation, storage and processing of the produce (Beuchet, 1996). All the bacteria isolated in this study have previously been isolated from fruits and vegetable in other studies in India and elsewhere (Khan et al., 1992; Mosupuye and Holy, 1999; Viswanathan and Kaur, 2001; Sivapalasingam et al., 2004; Tambedkar and Mundhada, 2006; Ankita Rajvanshi, 2010).

Table 4: Showing the percentage of prevalent ESBL producing Enterobactericeae on vegetables of Aizawl markets.

\begin{tabular}{llll}
\hline $\begin{array}{l}\text { Sl. } \\
\text { No. }\end{array}$ & $\begin{array}{l}\text { Organisms } \\
\text { (Enterobacteriaceae } \\
\text { members) }\end{array}$ & $\begin{array}{l}\text { Percentage } \\
\text { of isolation }\end{array}$ & $\begin{array}{l}\text { Percentage } \\
\text { of ESBL }\end{array}$ \\
\hline 1. & Escherichia coli & $2(5.40 \%)$ & $1(2.70 \%)$ \\
2. & Enterobacter sp. & $16(43.24 \%)$ & $9(24.32 \%)$ \\
3. $\quad$ Klebsiella sp. & $11(29.73 \%)$ & $11(29.73 \%)$ \\
4. Proteus sp. & $4(10.81 \%)$ & $2(5.40 \%)$ \\
5. Citrobacter sp. & $2(5.40 \%)$ & 0 \\
$6 . \quad$ Serratia sp. & $2(5.40 \%)$ & 0 \\
Total ( $=37)$ & $37(100 \%)$ & $23(62.16 \%)$ \\
SD values & 16.074 & 13.176 \\
SEM & 6.562 & 5.329 \\
$p$ value (one tail) & 0.0324 & \\
\end{tabular}

The higher microbial load observed in the fruits and vegetables in this current study may be a reflection of storage conditions and how long these produce were kept before they were obtained for sampling. Bacteria on storage may get transferred from one to another vegetable during pre-washing by some contaminated water, kept in a bag used for long time storage where bacteria may multiply over time depending on the storage conditions especially those are psychotropic and mesophilic (Montville and Mathews, 2008). The high bacteria counts observed from fruits and vegetables in this current study are similar to those obtained in other studies in India (Viswanathan and Kaur, 2001).

The presence of $S$. aureus, a pathogenic organism of public health concern, in most of the samples and the presence of other pathogenic and opportunistic bacteria like E. coli, Proteus spp. and Klebsiella spp. in some of the fruits and vegetables, further highlights the need to safeguard the health of the consumers by proper washing and decontamination of these produce which are consumed without heat treatment.

Enterobacter spp. (39.02\%) was the most common isolate in all the three sample groups of the current study. These findings are analogous to the reports from Finland and Nigeria. A higher rate of Enterobacter spp. prevalence was reported in Finland and showed that $38.3 \%$ of all the three samples used i.e. Fresh Finnish, Fresh imported and Frozen imported (Monica et al., 1999). Enterobacter 
aerogenes were also found in higher percentage (56\%) of prevalence in vegetable salads sold at restaurants of Okada town, Edo State, Nigeria (Osamwonyi et al., 2013).

Mosupuye and Von Holy (1999) reported the presence of Salmonella in street foods in South Africa. Viswanathan and Kaur (2001) showed the presence of Salmonella, Serratia, Enterobacter, Staphylococcus aureus, faecal E. coli and $P$. aeruginosa in vegetables and fruits. The present study also showed the presence of $E$. coli, Enterobacter, Serratia and Staphylococcus in fresh vegetables collected from three different vendors. WHO (2002) reported that Salmonella spp. causes Salmonellosis and typhoid fever and E. coli 0157: $\mathrm{H} 7$ causes severe illness and deaths, especially among children in several countries. Although the species distribution in our material, with very few $E$. coli, the dominant aerobic rod in fecal flora, suggests that fecal contamination rate is rare.

Antimicrobial agents are used widely as food additives to improve growth and feed conversion in many types of animal operations, including poultry, swine and cattle operations. And in humans misuse of antibiotics or self medication is so common. As a result, antibiotic resistance in the bacterial communities in the intestinal tracts of domestic animals and in humans has become common (Aerestrup et al., 2000). The emergence of drug resistance is one of the most serious health problems in developing countries like India. In this study, the high antibiotic resistance rate $(80.5 \%)$, numerous resistance pattern and high ESBL producing pathogens (62.16\%) were found prevalent in the vegetables. Thus the material in this study gives a more reliable picture of the resistance levels that can be expected in most Enterobacteriaceae on vegetable in North East India.

Multi drug resistance (MDR) pattern was observed in almost all the strains isolated. Among the 41 strains isolated $33(80.5 \%)$ were MDR strains which are very high compared to previous report by the author in UTI patients from the same study area (Karuppasamy and Lalsanglura, 2012). Of those, except Serratia spp. all other strains were found resistant to more than 5 drugs at least. Drug resistance percentage is increased in comparison to the previous study, Nitrofurantoin $27.16 \%$ increased to 65.85 $\%$, Amikacin $7.41 \%$ increased to $26.82 \%$ and $0 \%$ strains were resistant to Meropenem and Imepenem which is now showing $12.19 \%$ and $17.01 \%$ respectively in this study.

\section{ESBLs}

Extended Spectrum $\beta$ Lactamases (ESBLs) are a group of enzymes that have the common property of providing resistance to extended-spectrum $\beta$ lactam antibiotics such as Oxyimino cephalosporins (e.g. cefotaxime, ceftazidime, ceftriaxone, cefepime and cefpirome), as well to aztreonam an oxyimino monobactam, Cephamycins (Cefoxitin and cefotetan) and Carbapenems (Imepenem and Meropenem) (Oreste, 2003). In this study 23 $(62.16 \%)$ strains out of 37 GNB found to be positive for the ESBLs double disk synergy test (DDST) (CLSI, 2012). This indicates that the resistance genes might have transferred to the pathogens of vegetables from human pathogens or vice versa. This high prevalence of ESBLs resistance bacteria on the fresh vegetables is representing a high potential health risk to human population consumes or exposed to these vegetables of the current study locations.

\section{CONCLUSION}

To limit the introduction of pathogenic bacteria to vegetables through irrigation, the origin and distribution of irrigation water should be known. Where there are wells used, wells should be well-maintained, and all irrigation sources should be monitored routinely for human pathogens (Buck et al., 2003). Manure used as fertilizer should be treated either by composting or aging to eliminate pathogenic microorganisms and farmers should be educated about the manure application and harvest. Fruits and vegetables processor should be educated on the adverse effect of using untreated or polluted water for contamination. Processors/vendors should also observe strict hygienic measures to ensure that they do not serve as a source of chance for inoculation of microorganisms/contamination. There is need to make a law compelling vendor, in Aizawl, to transport/sell fresh fruits and vegetables in cool temperature controlled carts similar to those used for the transport /sales of yogurt and ice creams.

\section{ACKNOWLEDGEMENTS}

This mini project is not a part of any funding agencies. We are very great full to the Head, Department of MLT for his constant support and helped to get the materials and chemicals required for this current project to be completed. We are thankful to our Director, who sanctioned the fund to get all the materials, chemicals indented from our department. We are thankful to Mr. Lalnunpuia Chhangte, Computer Operator, RIPANS for his help in making the graphs and tables.

\section{REFERENCES}

Aarestrup, F. M., Agerso, Y., Smidt, P. G., Madsen, M. and Jensen, L. B. (2000). Comparison of antimicrobial resistance phenotypes and resistance genes in $E$. faecalis and E. faecium from humans in the community, broilers and pigs in Denmark. Diagnostic Microbiology and Infectious Diseases 37, 127-137.

Ankita, R. (2010). Bacterial load on street vended salads in Jaipur City, India. Internet Journal of Food Safety 12, 136-139.

Bauer, A. W., Kirby, M. D. K., Sherries, J. C. and Truck, M. (1966). Antibiotic susceptibility testing by a standardized single disk method. American Journal of Clinical Pathology 45, 493-496.

Beuchat, L. R. (1996). Pathogenic microorganisms associated with fresh produce. Journal of Food Protection 59, 204-216. 
Buck, J. W., Walcott, R. R. and Beuchat, L. R. (2003). Recent trends in microbiological safety of fruits and vegetables. Plant Health Progress 10, 1094.

Carmo, L. S., Cummings, C., Linardi V. R., Dias, R. S., Souza, J. M., Sena, M. J., Santos, D. A., Shupp, J. W., Pereira, R. K. and Jett., M. (2004). A case study of a massive staphylococcal food poisoning incident. Food Borne Pathogens and Disease 1, 241-246.

C. D. C. (2005). National Antimicrobial Resistance Monitoring System (NARMS) Frequently Asked Questions (FAQ) About Antibiotic Resistance - Why is antibiotic resistance a food safety problem? Cdc.gov. http://www.cdc.gov/narms/faq pages/5.htm. [Retrieved on February, 2014]

Clinical Laboratory Standards Institute. M100-S22 (2012). Clinical and Laboratory Standards Institute: Performance Standards for Antimicrobial Susceptibility Testing. $22^{\text {nd }}$ Informational Supplement. (M100S22).Clinical and Laboratory Standards Institute. Vol. 31. No.1. January, 2012. Villanova. Pa. USA.

Collee, J. G., Fraser, A. G., Marmion, B. P., and A. Simmons. (2011). Mackie \& McCartney - Practical Medical Microbiology. $14^{\text {th }}$ edn. Churchill Livingston. New York.

Hasan, A., Utku, O. and Koray, K. (2006). Determination of total aerobic and indicator bacteria on some raw eaten vegetables from wholesalers in Ankara, Turkey. International Journal of Hygiene and Environmental Health 209, 197-201.

Holt, J. G., Kreyg, H. R. A., Standly, J. T. and Williams, S. T. (1994). Bergey's Manual of Determinative Bacteriology. $9^{\text {th }}$ edn. The Williams and Wilken Company, Baltimore, MD, USA.

Kalia, A. and Gupta, R. P. (2006). Fruit Microbiology. In: Handbook of Fruit and Fruit Processing. $1^{\text {st }}$ edn. Hui, Y. H. J., Cano, M. P., Gusek, W., Sidhu, J.W., Sinha, N. K. Blackwell Publishing.London. pp. 3-28.

Karuppasamy, C., and Lalsanglura, R. (2012). Resistance of the pathogens causing Urinary Tract Infections against antibiotics. Bioinfolet 9(3), 348-354.

Khan, M. R., Saha, M. L. and Kibria, A. M. (1992). A bacteriological profile of salad vegetables in Bangladesh with special reference to coliforms. Applied Microbiology 14, 88-90.

Kilonzo, N. A., Rotich, E. and Thompson, C. (2009). Antibiotic-resistant bacteria isolated from organic and conventional fresh produce. National Institute of Food Technology. $\quad$ http://www.reeis.usda. gov/web/crisprojectpages/213697.html [Retrieved on April 2014]

Kumar, K., Gupta, S. C., Baidoo, S. K., Chander, Y. and Rosen, C. J. (2005). Antibiotic uptake by plants from soil fertilized with animal manure. Journal of Environmental Quality 34, 2082-2085.

Lund, B. M. (1992). Ecosystems in vegetable foods. The Journal of Applied Bacteriology 73(s21), 115-135.
Monica, O., Pensala O., Margareta, P., Hans, H. and Pentti, H. (1999). Antimicrobial susceptibility of Enterobacteriaceae isolated from vegetables. Journal of Antimicrobial Chemotherapy 43, 503-509.

Montville, T. J. and Mathews, K. R. (2008). Food Microbiology: An Introduction. $2^{\text {nd }}$ edn. American Society of Microbiology (ASM) Press. Washington, DC.

Mosupuye, F. M., and von Holy, A. (1999). Microbiological quality and safety of ready to eat street vended foods in Johannesburg, South Africa. Journal of Food Protection 62(11), 1278-1284.

Nguyen-the, C. and Carlin, F. (1994). The microbiology of minimally processed fresh fruits and vegetables. Critical Reviews in Food Science and Nutrition 34, 371-401.

Nyenje, M. E., Odjadjare, C. E., Tanih, N. F., Green, E. and Ndip, R. N. (2012). Food borne pathogens recovered from Ready-to-Eat Foods from roadside cafeterias and Retail outlets in Alice, Eastern Cape province, South Africa: Public Health Implications. International Journal of Environmental Research and Public Health 9, 2608-2619.

Ofor, M. O., Okorie, V. C., Ibeawuchi. I. I., Ihejirika, G. O., Obilo, O. P. and Dialoke, S. A. (2009). Microbial contaminants in fresh tomato wash water and food safety considerations in South-Eastern Nigeria. Life Science Journal 1, 80-82.

Oreste, A. M. (2003). Bacteria versus antibacterial agents, an integrated approach. American Society of Microbiology (ASM) Press. Washington, DC. pp. 172182.

Osamwonyi, O. U., Oboyagbona, O. N., Aborisade, T. W., Olisaka, F., Uwadiae, E. and Igiehon, 0 . N. (2013). Bacteriological quality of vegetable salads sold at restaurants within Okada town, Edo State, Nigeria. IOSR Journal of Pharmacy and Biological Sciences 5(2), 87-90.

Ray, B. and Bhunia, A. K. (2007). Fundamental Food Microbiology. $4^{\text {th }}$ edn. CRC Press, USA. pp. 492.

Sivapalasingam, S., Friedman, C. R., Cohen, L. and Tauxe, R. V. (2004). Fresh produce: A growing cause of outbreaks of food borne illness in the United States, 1973 through 1977. Journal of Food Microbiology 58, 123-128.

Tambekar, D. H. and Mundhada, R.H. (2006). Bacteriological quality of salad vegetables sold in Amravati City (India). Journal of Biological Sciences 6(1), 28-30.

Viswanathan, P. and Kaur, R. (2001). Prevalence and growth of pathogens on salad vegetables, fruits and sprouts. International Journal of Hygiene Environmental Health 203(3), 205-213.

World Health Organization. (2002). WHO global strategy for Food Safety: Safer Food for Better Health. Food Safety Issues, WHO, Geneva. pp. 26. 